\title{
EFFECT OF NATURAL ANTIOXIDANTS ON THE PHYSICOCHEMICAL PROPERTIES AND STABILITY OF FREEZE-DRIED MICROENCAPSULATED CHIA SEED OIL
}

Running title: Freeze-dried microparticles with chia seed oil and natural antioxidants

Erica S. Rodriguez ${ }^{2}$, Luciana M. Julio ${ }^{1}$, Cynthia Henning ${ }^{2}$, Bernd W.K. Diehl ${ }^{3}$, Mabel C.

Tomás ${ }^{1}$, Vanesa Y. Ixtaina ${ }^{\star 1,2}$

${ }^{1}$ Centro de Investigación y Desarrollo en Criotecnología de Alimentos (CIDCA) - (UNLP -

CONICET). Calle 47 y 116 (1900), La Plata, Argentina vanesaix@hotmail.com,

vixtaina@agro.unlp.edu.ar, mabtom@hotmail.com, luci julio86@hotmail.com

${ }^{2}$ Facultad de Ciencias Agrarias y Forestales- UNLP. Calle 60 y 119 (1900), La Plata,

Argentina ery115@hotmail.com, cynthiaphenning@yahoo.com.ar

${ }^{3}$ Spectral Service GmbH Laboratorium für Auftragsanalytik, Emil Hoffman Str. 33, D-

50996 Cologne, Germany

* Corresponding author: Vanesa Y. Ixtaina, Centro de Investigación y Desarrollo en

Criotecnología de Alimentos (CIDCA - CONICET) - Facultad de Ciencias Exactas (FCE-

UNLP), 47 y 116 (1900), La Plata, Argentina.

Phone/Fax: +54 221425 4853/424-9287/489-0741.

E-mail address: vanesaix@hotmail.com

This article has been accepted for publication and undergone full peer review but has not been through the copyediting, typesetting, pagination and proofreading process, which may lead to differences between this version and the Version of Record. Please cite this article as doi: $10.1002 /$ jsfa.9355 


\section{ABSTRACT}

BACKGROUND: Chia oil possesses a very high content of polyunsaturated fatty acids, mainly $\alpha$-linolenic acid. This characteristic makes this oil possess beneficial properties to health but gives it a high susceptibility to the oxidation process. The microencapsulation and the addition of natural antioxidants are alternatives to protect chia oil against oxidative deterioration. The aim of this study was to investigate the physicochemical characteristics and the oxidative stability of chia seed oil microencapsulated with different natural antioxidants (Guardian Chelox, which is a commercial blend of extracts from chamomile and rosemary, and essential oils from Origanum vulgare, Origanum x majoricum, and Mentha spicata) by freeze-drying using sodium caseinate and lactose as wall materials. RESULTS: The main physicochemical properties of the microencapsulated chia oil were similar regardless the presence antioxidant. The moisture content was $38.1 \pm 4.0 \mathrm{~g} \mathrm{~kg}^{-1}$; the microencapsulation efficiency was higher than $85 \%$ in all cases. The freeze-drying microencapsulation significantly enhanced $(p \leq 0.05)$ the oxidative stability of the chia oil. The addition of natural antioxidants conferred chia oil additional protection against lipid oxidation, depending on the type and concentration (500 or $1000 \mathrm{mg} \mathrm{kg}^{-1}$ of the emulsion previous to freeze-drying) of the antioxidant. Among them, Guardian Chelox (1000 mg kg $\left.{ }^{1}\right)$, presented the highest induction time obtained by the Rancimat accelerated oxidative stability test $(\mathrm{t})$ and the lowest peroxide values after $90 \mathrm{~d}$ of storage $\left(33 \% \mathrm{RH}, 25 \pm 2^{\circ} \mathrm{C}\right)$. Overall, the microparticles with antioxidants presented a lower degree of yellowing during storage than the control system.

CONCLUSION: The use of different natural antioxidants confers freeze-dried microencapsulated chia seed oil additional protection against lipid oxidation. This

This article is protected by copyright. All rights reserved. 
information is relevant for the application of this oil, which is a rich source of omega- 3 fatty acids, in the food industry.

Keywords Chia oil; Omega-3 fatty acids; Microencapsulation; Natural antioxidants;

Essential oils

\section{INTRODUCTION}

The oil obtained from chia seeds (Salvia hispanica L.) is rich in essential polyunsaturated fatty acids (PUFAs) $(>80 \%)$, mainly omega-3 ( $\alpha$-linolenic acid), which makes this oil possess beneficial properties to health. However, the high PUFAs content gives chia oil low stability to the oxidation process. The microencapsulation is a technique to protect and deliver different sensitive compounds, such as those present in chia oil, from the adverse influence of the environment. Recently, studies about chia seed oil microencapsulation have been carried out using different wall materials, microencapsulation processes and storage conditions ${ }^{1-6}$.

The microencapsulation can be carried out by different methods, such as spraydrying and freeze-drying. The former is the most common process used in the industry because of its relatively low cost. However, the freeze-drying process is recognized as a method to produce high-quality dried food products as the drying is conducted under vacuum and at temperatures lower than ambient temperature ${ }^{7}$. This characteristic makes the freeze-drying process especially attractive for drying heat-sensitive and bioactive components, such as chia seed oil, minimizing the product damage caused by the high temperatures applied in the spray-drying process.

The selection of the wall materials is a determining point in developing microencapsulated oils since their properties affect the characteristics of the final product. As no single wall material possesses all the properties required of an ideal encapsulating agent, the use of a combination of proteins and carbohydrates has been found to be an

This article is protected by copyright. All rights reserved. 
excellent alternative for microencapsulation ${ }^{8}$. Sodium caseinate rapidly confers low interfacial stress during emulsification previous to the drying process, and it is also a convenient wall material because of its good film-forming properties. On the other hand, lactose forms a continuous glass phase in which the protein chains are dispersed, thus improving the drying properties of the wall ${ }^{9}$. Different studies have shown high microencapsulation efficiency using these wall materials to encapsulate chia seed oil. In this sense, the mixture of a relatively low-cost carbohydrate such as lactose and sodium caseinate would be a cost-effective, functional, fat encapsulating alternative ${ }^{2,10,11}$.

Another alternative to protect chia oil against oxidative deterioration is the use of antioxidants ${ }^{12}$. They are an extensive group of chemical compounds, synthetic or from natural sources, which can inhibit or retard oxidation processes. Although the food industry has been using synthetic antioxidants for a long time, their safety is questioned and exist doubts about the hazards on human health. This fact has led to a trend of the progressive substitution of synthetic antioxidants for the natural ones ${ }^{13}$.

The antioxidants from plant sources, such as tocopherols, vitamin C, and flavonoids, are compounds of great value in the diet that can help to reduce the incidence of chronic diseases. Besides, there is a growing interest in the use of these natural antioxidants for extending the shelf-life of foods ${ }^{14}$.

Spices and aromatic plants are mainly known for their antimicrobial activity with many applications in food preservation, pharmaceuticals, alternative medicine, and natural therapies. Besides, many essential oils from these plants are also known as natural antioxidants ${ }^{15}$. Many genera belonging to the Lamiaceae family, such as Origanum, Rosemary, and Mentha, posses biological and pharmacological activities. Different authors have reported that Origanum vulgare L. essential oil contains a high amount of polyphenols with antioxidant properties due to the presence of thymol and carvacrol, and a

This article is protected by copyright. All rights reserved. 
synergistic effect among compounds containing oxygen ${ }^{16,17}$. Origanum $x$ majoricum Cambess, a hybrid between $O$. majorana $\mathrm{L}$. and $O$. vulgare $\mathrm{L}$., has a very high total phenolic content and its antioxidant activity against linoleic acid oxidation was comparable to that of $\mathrm{BHA}{ }^{18}$. Concerning rosemary extract (Rosmarinus officinalis L.), it has potent antioxidant activity due to the presence of phenolic diterpenes, mainly carnosic acid and carnosol and other minor compounds such as rosmanol, epirosmanol and methoxyepirosmanol ${ }^{19}$. It is marketed in an oil-soluble or water-miscible form or as a dry powder ${ }^{15}$. Regarding Mentha genus, it showed a high radical scavenging capacity due to the presence of monoterpene ketones (menthone, isomenthone) ${ }^{20}$. The antioxidant action of Mentha sp. could also be due to the presence of aldehydes and substances with phenolic rings. In this sense, the phenolic compounds would act as donors of electrons or hydrogen atoms, stabilizing free radicals ${ }^{21}$.

Moreover, species such as Matricaria chamomilla L (Asteraceae) has also presented antioxidant activity. Extracts and essential oil from this plant exhibited a high antioxidant and antimicrobial activity associated with a high total polyphenols content ${ }^{22}$. Besides, this species used in folk medicine for a long time, presents important antiinflammatory, anti-neoplastic and immunoregulatory effects ${ }^{23}$.

Few studies about microencapsulation of chia oil with natural antioxidants have been carried out ${ }^{24}$, with no information published about the influence of different vegetable extracts or essential oils on the oxidative stability of chia seed oil microencapsulated with sodium caseinate and lactose by freeze-dried.

The objective of this study was to investigate the effect of the addition of natural antioxidants (commercial blend of chamomile and rosemary extracts, essential oils from $O$. vulgare, $O$. x majoricum and Mentha spicata $\mathrm{L}$ ) on the physicochemical properties and

This article is protected by copyright. All rights reserved. 
oxidative stability of the chia seed oil microencapsulated by freeze-drying using sodium caseinate and lactose as wall materials.

This article is protected by copyright. All rights reserved. 


\section{MATERIALS AND METHODS}

\section{Materials}

Chia cold-pressed oil was supplied by Nutracéutica Sturla S.R.L (Burzaco, Buenos Aires, Argentina). Sodium caseinate (purity $>97 \%$ ) was purchased from Sigma Chemical Company (St. Louis, MO, USA) and d-lactose monohydrate (purity >98\%) from Anedra S.A. (San Fernando, Buenos Aires, Argentina). All reagents were analytical grade.

Guardian Chelox L, a commercial blend of chamomile and rosemary extracts with propylene glycol as carrier, was provided by Danisco USA Inc. (Madison, WI, USA). This blend contained $3.6 \mathrm{~g} \mathrm{~kg}^{-1}$ of total flavonoids and $2.8 \mathrm{~g} \mathrm{~kg}^{-1}$ of apigenin-7 glycosid according to the manufacturer.

\section{Chia seed oil characterization}

Fatty acid composition was analyzed by GC according to IUPAC 2.302 standard method ${ }^{25}$. Tocopherols were evaluated by normal phase HPLC with a Hewlett Packard system (HPLC Hewlett Packard 1050 Series, Waldbronn, Germany) equipped with a fluorescence detector Agilent 1100 Series (Agilent Technology, Palo Alto, CA, USA) ${ }^{26}$.

\section{Extraction and characterization of essential oils from Origanum vulgare $L$., Origanum x majoricum Cambess, and Mentha spicata $L$.}

Peppermint and both species of oregano, originally coming from Villa Dolores (Córdoba Province, Argentina), were established on weed-free plots in an experimental field situated in La Plata, Argentina ( $34^{\circ} 52^{\prime} \mathrm{S}$ latitude and $57^{\circ} 58^{\prime} \mathrm{W}$ longitude, Typic Argiudoll soil). Crops were propagated vegetatively from plantings of the previous year, in spring (September) and autumn (May) using peppermint and oregano shoots, respectively. The harvesting was carried out during bloom (December-January), and the material collected

This article is protected by copyright. All rights reserved. 
was dried in a forced-draft oven $(200 \mathrm{~cm} \times 160 \mathrm{~cm} \times 80 \mathrm{~cm})$ at $40^{\circ} \mathrm{C}$ until to reach a constant weight. The volatile fraction was extracted by steam hydrodistillation with a Clevenger-type apparatus according to the European Pharmacopoeia ${ }^{27}$. Then, the volatile distillate was collected over anhydrous sodium sulfate and refrigerated until the chromatographic analysis was carried out.

The GC-MS analysis was performed using a gas chromatograph Finnigan TRACE GC (ThermoQuest, Milan, Italy) coupled to a mass spectrometer Finnigan TRACE MS (ThermoQuest, Manchester, GB) with a quadropole mass analyzer, electron impact ionization (70 eV), and autosampler A200S (CTC Analytics, Zwingen, CH). A Zebron ZB-5 MSi capillary column (30 $\mathrm{m} \times 0.25 \mathrm{~mm}, 0.25 \mu \mathrm{m}$ film thickness) was used. Helium was used as carrier gas at a flow rate of $1.0 \mathrm{~mL} / \mathrm{min}$. The inlet was operated in split mode (ratio $1: 20)$ with an injection volume of $2.0 \mu \mathrm{L}$ of the essential oil diluted in methyl-t-butyl ether (MTBE). The $\mathrm{GC}$ temperature program used was $50^{\circ} \mathrm{C}(5 \mathrm{~min})$ and $10^{\circ} \mathrm{C} / \mathrm{min}$ up to $280^{\circ} \mathrm{C}(12 \mathrm{~min})$. Scan time and the mass range were $0.9 \mathrm{~s}$ and $15-650 \mathrm{~m} / \mathrm{z}$, respectively. The data analysis was made using a computer P3 $800 \mathrm{MHz}$ under Windows NT 4.0 and ThermoQuest Software Xcalibur 1.2.

The identification of the essential oils compounds was carried out comparing their relative retention times with those of the authentic samples (Carl Roth $\mathrm{GmbH}$, Karlsruhe, Germany). For the components whose authentic substances were not available, their identification was made by matching their El mass spectra with NIST/NBS, Wiley libraries spectra, and with the literature data ${ }^{28}$.

\section{Preparation of oil-in-water (O/W) emulsions}

Nine different $\mathrm{O} / \mathrm{W}$ emulsions (total solid content $=300 \mathrm{~g} \mathrm{~kg}-1$ of the emulsion) containing chia seed oil (100 g kg -1 of the emulsion) and natural antioxidants were prepared (Table 1). To obtain the aqueous phases sodium caseinate (NaCas) (100 g kg-1 of the emulsion)

This article is protected by copyright. All rights reserved. 
was dispersed in deionized water under constant stirring at $50^{\circ} \mathrm{C}$ for $3 \mathrm{~h}$. After that, lactose (100 $\mathrm{g} \mathrm{kg}-1$ of the emulsion) was added to the NaCas dispersions while stirring at $25^{\circ} \mathrm{C}$. These dispersions were stored overnight at $4^{\circ} \mathrm{C}$ to achieve the complete dissolution of these polymers. The essential oils from both species of Origanum and M. spicata were added into the oil phases, whereas the Guardian Chelox was incorporated to the aqueous phases, to achieve antioxidant concentrations of 500 or $1000 \mathrm{mg} \mathrm{kg}-1$ of the emulsion in all cases.

The oily and the aqueous phases were blended using an Ultra-Turrax T25 high-shear probe mixer (Janke \& Kunkel GmbH, Staufen, Germany) operated at 10,000 rpm for $60 \mathrm{~s}$ to give pre-emulsions. The resultant pre-emulsions were further homogenized at 600 bar with four recirculation cycles using a high-pressure laboratory valve homogenizer (Panda 2K, GEA Niro Soavi, Parma, Italy).

About $100 \mathrm{~g}$ of emulsion were placed in a tray $(12.5 \mathrm{~cm} \times 16 \mathrm{~cm})$ with a thickness of 10 $\mathrm{mm}$ and frozen at $-20 \pm 2{ }^{\circ} \mathrm{C}$ until further freeze-drying.

\section{Preparation of microencapsulated chia seed oil by freeze-drying}

Immediately $24 \mathrm{~h}$ previous to freeze-drying, samples were transferred at $-80 \pm 2^{\circ} \mathrm{C}$. A laboratory scale freeze-drying equipment with a capacity of $\sim 500 \mathrm{~g}$ per batch was used to dry the frozen emulsions. The time needed for drying one batch was $48 \mathrm{~h}$.

The dried samples were ground in a mortar and sifted using a plastic sieve (equivalent to ASTM No. 7) to obtain powders particles $<2.83 \mathrm{~mm}$.

\section{Characterization of the microparticles}

\section{Moisture content}

This article is protected by copyright. All rights reserved. 
The moisture content of the chia oil powders $(2 \mathrm{~g})$ was measured by drying the samples for $24 \mathrm{~h}$ at $70 \stackrel{\circ}{ } \mathrm{C}$ and 29 in $\mathrm{Hg}$ in a vacuum oven (Instrumentación Científica S.A., Buenos Aires, Argentina). Moisture content was calculated from the weight difference ${ }^{29}$.

\section{Microencapsulation efficiency}

To analyse the no encapsulated oil fraction (free oil), $4 \mathrm{~g}$ of powder was mixed with 200 $\mathrm{mL}$ of hexane and stirred for $15 \mathrm{~min}$. The mixture was filtered (Whatman No. 4) and the solvent was evaporated at $40^{\circ} \mathrm{C}$ in a rotary vacuum evaporator (Büchi, Flawil, Switzerland) ${ }^{30}$. The total oil content of the microparticles was analyzed by the RosseGottlieb method ${ }^{2}$.

Microencapsulation efficiency (ME), expressed as percentage of total oil, was calculated from the Eq. 1:

$$
\text { ME }(\%)=\left(\frac{\text { Total Oil-Free Oil }}{\text { Total Oil }}\right) \times 100
$$

\section{Morphological analysis by Scanning Electron Microscopy (SEM)}

Scanning electron microscopy (SEM) was used to study the microparticles morphology and size. The microparticles were metalized with gold film (600 Å) in a sputter coater (Pelco 9100, Clovis, CA, USA). The samples were observed using a MA10 instrument (Carl Zeiss SMT Ltd., Cambridge, UK) under high vacuum mode operating at $5 \mathrm{kV}$.

\section{Flowing properties}

The aerated $\left(\rho_{A}\right)$ and tapped $\left(\rho_{T}\right)$ bulk densities were determined according to a modified method of Quispe-Condori, Saldaña and Temelli ${ }^{31}$. About $25 \mathrm{~g}$ of each sample $\left(m_{0}\right)$ was poured through a funnel into a $100 \mathrm{~mL}$ glass graduated cylinder. Then, the cylinder was

This article is protected by copyright. All rights reserved. 
slightly tapped to collect the powder sticking to the wall of the cylinder. The volume $\left(V_{0}\right)$ was read directly from the cylinder and used to calculate $\rho_{A}$ according to Eq. 2:

$$
\rho_{A}=\frac{m_{0}}{V_{0}}
$$

For $\rho_{T}$, the cylinder was tapped until a constant volume $\left(V_{T}\right)$ was reached. $\rho_{T}$ was calculated as follows:

$$
\rho_{T}=\frac{m_{0}}{V_{T}}
$$

Results of $\rho_{A}$ and $\rho_{T}$ were expressed as $\mathrm{kg} \mathrm{m}^{-3}$.

The powder flowability was evaluated using the Carr's Index or "percent compressibility" $(C)$ and the Hausner Ratio $(H)$, using Eqs. 4 and 5, respectively:

$$
\begin{gathered}
C=\frac{\rho_{T} \rho_{A}}{\rho_{T}} \times 100 \\
H=\frac{\rho_{T}}{\rho_{A}}
\end{gathered}
$$

\section{Colour}

A Minolta colorimeter (CR-400, Konica Minolta Sensing Inc., Japan) was used to record L* (lightness), $\mathrm{a}^{*}$ (red-green component), and b* (yellow-blue component) values of samples. The samples were homogeneously distributed in a glass Petri dish (diameter $95 \mathrm{~mm}$ ) with a thickness of $15 \mathrm{~mm}$. For each sample, two color measurements with three replications each one was done in different regions of the Petri dish and averaged ${ }^{32}$. Whiteness index (WI) was calculated as described by Marcone and Kakuda ${ }^{33}$, according to Eq. 6.

$$
W I=L^{*}-3 b^{*}
$$

The yellowness index $(\mathrm{YI})$ was calculated as follows ${ }^{34}$ :

$$
Y I=\frac{142.86 \times b^{*}}{L^{*}}
$$

This article is protected by copyright. All rights reserved. 
The change of color after $90 \mathrm{~d}$ of storage was followed by the $\Delta \mathrm{E}$ index, which was obtained by Eq. $8^{35}$

$$
\Delta E=\sqrt{\left[\left(\Delta L^{*}\right)^{2}+\left(\Delta a^{*}\right)^{2}+\left(\Delta b^{*}\right)^{2}\right]}
$$

\section{Peroxide value (PV)}

PV was determined spectrophotometrically according to Mancuso, McClements and Decker ${ }^{36}$. A sample of $0.5 \mathrm{~g}$ of powder was weighed into a test tube, suspended in $5 \mathrm{~mL}$ of distilled water and shaking until complete powder dissolution. An aliquot $(300 \mu \mathrm{l})$ of this dispersion was shacked in a vortex apparatus for $10 \mathrm{~s}$ with $1.5 \mathrm{~mL}$ of an isooctane/isopropanol solution (3:1 v:v) and then centrifuged for $2 \mathrm{~min}$ at $3400 \mathrm{~g}$. A portion of the upper phase (10-100 $\mu$ l) was mix with $2.8 \mathrm{~mL}$ of a methanol/butanol solution (2:1 $\mathrm{v}: \mathrm{v})$ and $30 \mu \mathrm{L}$ of a thiocyanate/ferrous solution. This latter was prepared by mixing 0.144 $\mathrm{M} \mathrm{FeSO}_{4}$ and $0.132 \mathrm{M} \mathrm{BaCl}_{2}(1: 1 \mathrm{v} / \mathrm{v})$, centrifuging $3 \mathrm{~min}$ and then, mixing the clear ferrous phase with $3.94 \mathrm{M} \mathrm{NH}_{4} \mathrm{SCN}(1: 1 \mathrm{v} / \mathrm{v})$. After 20 min the absorbance was measured at $510 \mathrm{~nm}$. Lipid hydroperoxide concentrations were determined using cumene hydroperoxide standard curve. The analyses were carried out in duplicate.

\section{Accelerated oxidative stability by Rancimat}

Accelerated oxidation tests for bulk and microencapsulated oil were performed using a Rancimat model 743 (Metrohm AG, Herisau, Switzerland). Particularly, $3 \mathrm{~g}$ of chia oil or $1.5 \mathrm{~g}$ of powder were heated under air flow rate of $20 \mathrm{~L} / \mathrm{h}$ at $98^{\circ} \mathrm{C}$. The induction times $\left(\mathrm{t}_{\mathrm{i}}\right)$ expressed in hours were recorded to study the oxidative stability ${ }^{37}$.

This article is protected by copyright. All rights reserved. 


\section{Storage of microparticles}

The storage of the powders and the chia bulk oil was carried out in glass Petri dishes (95 $\mathrm{mm} \times 15 \mathrm{~mm}$ ) or glass beaker $(50 \mathrm{~mL})$, respectively, at a relative humidity of $33 \%, 25 \pm 2^{\circ} \mathrm{C}$ in the dark, for 90 days. Aliquots of the samples were taken periodically for color and PV analysis. The assay was carried out in duplicate.

\section{Statistical analysis}

Analyses were carried out in duplicate for all tests, and results presented as the average \pm standard deviation (SD). Data were analysed using a one way analysis of variance (ANOVA) and Tukey test $(p \leq 0.05)$. Relationships between variables were studied using correlation analysis by Pearson's test. The Statgraphics Centurion XV software (StatPoint, Inc., USA) was used for the statistical analysis.

This article is protected by copyright. All rights reserved. 


\section{RESULTS AND DISCUSSION}

\section{Characterization of chia oil}

According to chia oil fatty acids (FA) composition results, the main FA was $\alpha$-linolenic acid (C18:3n-3) (64.59 $\pm 0.09 \%)$, followed by linoleic (C18:2n-6) (19.74 $\pm 0.36 \%)$ and oleic (C18:1n-9) (6.49 $\pm 0.01 \%)$ FA. Also, chia oil presented palmitic (C16:0) $(7.30 \pm 0.02 \%)$ and stearic (C18:0) (2.21 $\pm 0.01 \%)$ FA. The $n-3 / n-6$ FA ratio of chia oil was 3.3 , which is noticeably higher in comparison to those reported from other vegetable oils, e.g. canola oil (0.45), soybean oil $(0.15)$, and olive oil $(0.13)^{38}$. These results agree with findings reported in previous studies ${ }^{39,40}$ Chia oil also exhibited a total tocopherol content of $330.95 \pm 6.61$ $\mathrm{mg} \mathrm{kg}^{-1}$ oil. Similar total tocopherol content $\left(238-427 \mathrm{mg} \mathrm{kg}^{-1}\right)$ was informed by Ixtaina et al. ${ }^{40}$. In this sense, although chia oil presents a FA composition favorable from a nutritional point of view and possess natural antioxidants, the high amount of PUFAs results in a low oxidative stability.

\section{Characterization of essential oils}

The obtained yields of essential oils, expressed in dry matter, were $2.10 \pm 0.01 \%(\mathrm{v} / \mathrm{wt})$, $3.35 \pm 0.02 \%(\mathrm{v} / \mathrm{wt})$ and $2.50 \pm 0.01 \%(\mathrm{v} / \mathrm{wt})$ for M. spicata, O. vulgare, and O. x majoricum, respectively.

The major components of the three essential oils studied are listed in Table 2. As can be seen, O. x majoricum presented a higher number of different compounds than O. vulgare. Nine compounds ( $>1 \%$ ) were identified in the essential oil of $O$. vulgare, being the monoterpene carvacrol the main component $(72.00 \%)$. Other compounds were cymol $(13.42 \%)$ and $y$-terpinene (6.96\%) and in minor concentrations $\beta$-myrcene $(1.30 \%)$, $\alpha$ terpinene (1.40\%), and caryopyllene (1.00\%) (Table 2). The chemical profile of the $O . x$ majoricum exhibited twelve compounds with concentrations $>1 \%$ including thymol

This article is protected by copyright. All rights reserved. 
(26.20\%), terpineol (23.10\%), and terpinen-4-ol (11.94\%). The GC-MS analysis also revealed the presence of carvacrol $(9.08 \%), \mathrm{v}-(5.79 \%)$ and $\alpha$-terpinene $(3.66 \%)$ in this essential oil. In the case of $M$. spicata, their composition presented seven compounds (>1\%). The main components of this essential oil were carvone $(45.36 \%)$, d-limonene (36.37\%), and menthone (5.05\%) while smaller amounts of dihydrocarveol $(3.08 \%), \beta-$ myrcene (2.15\%), menthol (1.90\%), and caryopyllene (1.20\%) were also detected.

\section{Characterization of the microparticles}

Table 3 shows the properties of the control microparticles obtained by freeze-drying using sodium caseinate and lactose as the wall materials.

The moisture content, ME, bulk density, compressibility index, Hausner ratio, and morphology of all different microencapsulated chia oil were found to be similar $(p>0.05)$ regardless the presence of the added antioxidant type. The moisture content of the chia oil microparticles was comprised within the recommended range for food powders $(30-40 \mathrm{~g}$ $\mathrm{kg}^{-1}$ dry basis). The ME provides information about which fraction of the total oil was efficiently microencapsulated. As can be seen in Table 3, the ME of the freeze-dried chia oil microparticles $(86.3 \pm 3.2 \%)$ was lower than those reported by Ixtaina et al. ${ }^{2}(\sim 95.0 \%)$ for microencapsulation of chia seed oil produced by spray-drying. The possible emulsion physical destabilization produced by the emulsifier dehydration during the freezing, previous to the freeze-drying process, could be the cause of the lower ME of freeze-dried microparticles in comparison with the spray-dried ones. Thus, the core material release can occur during the named stage ${ }^{7}$. Similar results were found by Copado et al. ${ }^{10}$. Regarding the bulk density, it varied between $310 \pm 10$ and $410 \pm 20 \mathrm{~kg} \mathrm{~m}^{-3}$ for aerated and tapped density, respectively (Table 3). Bulk density is an important parameter to describe food powders. It depends on the particle size, the water content in the product and the

This article is protected by copyright. All rights reserved. 
characteristics of the material. In general, a low bulk density of the powder is not desirable due to the requirement of a higher volume of the package ${ }^{26}$. Similar results of this parameter were obtained by Copado et al. ${ }^{10}$, with values of $\sim 301$ and $\sim 551 \mathrm{~kg} \mathrm{~m}^{-3}$ for aerated and tapped density, respectively. Also, Goyal et al. ${ }^{41}$ found an equivalent behavior for microencapsulated flaxseed oil powder using milk proteins.

The compressibility in many powders is a measure of internal cohesion, flowability, and in some extent, deformability. A low compressibility indicates a less cohesive powder and a higher bulk density ${ }^{42}$. This fact is important for the homogeneous character and reproducibility of the microparticles to be subsequently included in food products. The compressibility index resulted in $\sim 25 \%$, which is between the limit of free-flowing and nonfree flowing solid ${ }^{43}$. The $H$ also indicated that the obtained powder presented intermediate flowing properties. According to Geldart et al. ${ }^{44}$, this parameter allows to distinguish between easy $(H<1.25)$ and the difficult-to-fluidize $(H>1.4)$ powders. In our case, the studied microparticles recorded $H \sim 1.3$ with properties in common with both types of powders. It should be noted that the $H$ reflects the friction conditions in a moving mass of powder, not in a static situation ${ }^{44}$.

The scanning electronic micrographs (SEM) of microparticles containing chia oil are shown in Fig. 1. In general, the particles exhibited a sheet form with an irregular geometry and a compact structure. This shape is different from the microcapsules obtained by spray dried, which are spherical and regular ${ }^{2}$. Besides, the external topography of freeze-dried powders showed walls with the presence of some protrusions and some little pores, which could be related to the generation of cavities of ice crystals or air bubbles retained during freezing (Fig. 1d). ${ }^{32,45}$. Related to this, although the pores presence could not affect the microencapsulation efficiency, it would be a possible cause of lipid oxidation. In this sense, the literature suggests that particles highly porous could facilitate the diffusion of oxygen

This article is protected by copyright. All rights reserved. 
from the air onto the particle surface, which gets into the inner part of the particle due to the amorphous state of the matrix. However, the freeze-drying microencapsulation process was able to protect the chia seed oil against lipid oxidation, as discussed below.

\section{Effect of natural antioxidants on oxidative stability and colour of microencapsulated chia seed oil}

Nine systems of microencapsulated chia oil with and without the addition of natural antioxidants were studied.

The oxidative stability of the chia oil was enhanced using the freeze-drying microencapsulation since all systems presented significantly $(p \leq 0.05)$ higher values of $t_{i}$ (2.97-21.74 h) than those corresponding to bulk chia oil $(2.37 \pm 0.07 \mathrm{~h})$.

The accelerated oxidative test revealed that at the initial time ( $t=0 \mathrm{~d})$ the addition of Guardian Chelox $(G C H)$ significantly increased $(p \leq 0.05)$ the $t_{i}$ of the microencapsulated chia oil ( $\left.t_{i} \sim 20 h\right)$, without significant differences ( $\left.p>0.05\right)$ between both concentrations tested (GCH500 and GCH1000) (Fig. 2). The $t_{i}$ of samples with O. vulgare essential oils in both concentrations (Ov500 and Ov1000) did not show significant differences ( $p>0.05$ ) respecting the control system. Regarding $t_{i}$ of the microparticles with essential oils of $O . x$ majoricum (Om500 and Om1000) and M.spicata (M500 and M1000), they were significantly $(p \leq 0.05)$ lower than that of the control microencapsulated oil. At the end of the storage $(t=90 \mathrm{~d})$ all the samples recorded lower $t_{i}$ than that corresponding to $t=0 \mathrm{~d}$, which indicates the occurrence and evolution of the oxidative deterioration. However, GCH500, GCH1000, Ov500, Ov1000 and Om1000 systems showed higher values of $t_{i}$ than the control (Fig. 2). Among them, GCH1000, a blend of extracts from rosemary and chamomile, presented the highest $t_{i}$ thus showing to be the phenolic compounds from this antioxidant, the most effective to protect the microencapsulated chia oil from oxidation.

This article is protected by copyright. All rights reserved. 
This natural antioxidants blend, rich in flavones and phenolic acids, such as apigenin-7-Oglucoside, carnosic acid, and carnosol, provides a two-step protection in the form of metal chelation and free radical scavenging. GCH was used in model food emulsions and real food systems, showing a synergistic interaction between the rosemary and chamomile extracts $^{46}$.

The oxidative stability was also studied through the evolution of peroxide value (PV) during the microparticles storage in the dark at $25 \pm 2{ }^{\circ} \mathrm{C}$ and $33 \% \mathrm{RH}$ (Fig. 3). Initial PVs were low for all systems, suggesting that significant quantities of primary oxidation products were not detected immediately after the microencapsulation process. However, after $30 \mathrm{~d}$ of storage, there were some significant $(p \leq 0.05)$ differences. At this time, the control system showed a PV higher than the other ones and the chia bulk oil. The oxidation process involves a free radical chain mechanism proceeding via three steps: initiation, propagation, and termination ${ }^{47}$. Thus, the microencapsulation by freeze-drying could have promoted the initiation step; the addition of natural antioxidants could have protected the chia oil during this process. Notably, at this time, all PV values were below the limit allowed for this type of oil $\left(10 \mathrm{meq} \mathrm{kg}^{-1} \mathrm{oil}^{48}\right)$. After $60 \mathrm{~d}$ of storage, the control microencapsulated chia oil showed a PV significantly higher $(p \leq 0.05)$ than the other systems. Besides, the bulk chia oil started to steeply increase its PV. At this time ( $t=60 \mathrm{~d})$, both bulk and microencapsulated chia oil without antioxidants exceeded the upper limit established by the Codex Alimentarius ${ }^{48}$ for the consumption of this type of oil. At the final of the storage period ( $\mathrm{t}=90 \mathrm{~d}$ ), $\mathrm{GCH} 1000$ presented $\mathrm{PV}<10 \mathrm{meq} / \mathrm{kg}$ oil, showing that this blend of natural antioxidants was efficient to protect chia oil against lipid oxidation. Also, GCH500, Ov500 and Om1000 recorded PV 10 meq $/ \mathrm{kg}$, with no significant differences $(p>0.05)$ among them. The highest antioxidant efficiency of $\mathrm{GCH}$ could be related to the combination of

This article is protected by copyright. All rights reserved. 
rosemary and chamomile extracts. Different studies have shown that while the former has free-radical scavenger activity, the latest shows strong metal chelation ${ }^{47}$.

A study carried out by Danisco ${ }^{46}$ has shown that the GCH $\left(250-1000 \mathrm{mg} \mathrm{kg}^{-1}\right)$ used in mayonnaise, dressings, margarine, and spreads presented a similar antioxidant performance that EDTA $\left(75-150 \mathrm{mg} \mathrm{kg}^{-1}\right)$.

Changes in color are associated with the oxidation of triacylglycerols and free fatty acid since this process can produce colored products. Thus, the color can be a sign of the oxidative deterioration degree of foods with a high-fat content ${ }^{49}$.

At $t=0$, microencapsulated chia seed oil produced without antioxidants presented creamish color having mean values of $L^{*} 90.72, a^{*}-2.63$, and $b^{*} 16.29$ (Table 4). In general, when antioxidants were incorporated, the powders were off-white, with higher whiteness indices (W) than the control. Converesly, the yellowness indices $(\mathrm{Y})$ of powders with natural antioxidants were lower than the control system. This last index is related to the general product degradation caused by the processing conditions, light, temperature and chemical agents ${ }^{50}$. Therefore, the obtained results show that the addition of antioxidants could have protected microencapsulated chia seed oil during the microencapsulation process. After $90 \mathrm{~d}$ of storage all the systems presented changes in the color parameters. These color changes were very distintct for the system without antioxidants and those with the addition of M. spicata essential oils, whereas the rest of the microcapsules presented distinct color changes, according to the differences in perceivable color classification proposed by Adekunte et al. ${ }^{51}$ (very distinct $\Delta \mathrm{E}>3$, distinct $1.5<\Delta \mathrm{E}<3$ and small difference $1.5<\Delta \mathrm{E})$. The highest color change was recorded by the control system, followed by that with $500 \mathrm{mg} \mathrm{kg}^{-1}$ of $M$. spicata. No significant $(\mathrm{p}>0.05)$ differences were found between $\Delta \mathrm{E}$ of the rest of the powders. In general, at the end of the storage the powders were more yellowish as consequence of the colored products of the oxidation process. In this sense,

This article is protected by copyright. All rights reserved. 
a positive correlation was found between the $Y$ index at $t=90 d$ and the $P V$ at $30 d$ $(r=0.8018, p=0.0000), 60 d(r=0.8676, p=0.0000)$ and $90 d(r=0.7567, p=0.0000)$. Also a negative correlation was detected between the $W$ index and the PV at different storage times $\left(W\right.$ vs. $P V_{30 d} r=-0.7891 p=0.0000 ; W v s . P V_{60 d}=-0.8621, p=0.0000 ; W v s . P V_{30 d} r=-$ $0.7515 p=0.0000$ ). However, some differences were observed between the different systems. The highest $b^{*}$ value, which takes positive values for yellowish colours, was recorded in the control microparticles. In addition, the control system recorded the lowest $L^{*}$ and the highest $a^{*}$ values of all the samples, wich indicates that this system suffered the highest deterioration during the storage. Also, microparticles with $500 \mathrm{mg} \mathrm{kg}^{-1}$ of $M$. spicata recorded higher values of $b^{*}$ and $Y$, and lower $W$ than the other ones.

This article is protected by copyright. All rights reserved. 


\section{CONCLUSIONS}

This study provides an insight into the use of different natural antioxidants to give freezedried microencapsulated chia seed oil additional protection against lipid oxidation.

The addition of the natural antioxidants had no significant effect on the microencapsulation efficiency (>85\%), moisture content $\left(<40 \mathrm{~g} \mathrm{~kg}^{-1}\right)$, bulk density, compressibility index, Hausner ratio, shape, and surface condition of the microencapsulated chia seed oil. The microparticles were irregular with sheet-like shapes, a compact structure and with the presence of some protrusions.

Results of Rancimat analysis showed that the oxidative stability of the chia oil was improved by the freeze-drying microencapsulation since the initial $t_{i}$ of the microencapsulated chia seed oil was five times higher than the bulk oil. The addition of natural antioxidants further increased the $t_{i}$ of microencapsulated chia oil, depending on the type and concentration of the antioxidant. The best effects were recorded in microencapsulated chia seed oil with the addition of Guardian Chelox at both concentrations.

The evolution of hydroperoxide content, evidenced through the PV, showed that the systems with $1000 \mathrm{mg} \mathrm{kg}^{-1}$ of Guardian Chelox presented lower values than the upper limit allowed for this type of oil. Also, the addition of $500 \mathrm{mg} \mathrm{kg}^{-1}$ of Guardian Chelox and $O$. vulgare essential oil, and $1000 \mathrm{mg} \mathrm{kg}^{-1}$ of $O . x$ majoricum protected the chia oil, although to a lesser extent, presenting $\mathrm{PV} \sim 10 \mathrm{meq} \mathrm{kg}^{-1}$ after $90 \mathrm{~d}$ of storage at $25 \pm 2^{\circ} \mathrm{C}$ and $\mathrm{RH}$ $33 \%$.

Regarding color changes during storage, the addition of natural antioxidants, except $M$. spicata extract, had significant effect on this parameter, achieving a decrease in the degree of yellowing during the storage.

This article is protected by copyright. All rights reserved. 
Taking into account the results previously described, Guardian Chelox, an antioxidant based on the mixture of rosemary and chamomile extracts, was the most efficient of the natural antioxidants studied in conferring protection against oxidative deterioration to the microencapsulated chia oil.

\section{ACKNOWLEDGEMENTS}

This work was supported by grants from Agencia Nacional de Promoción Científica y Tecnológica (ANPCyT), Argentina (PICT 2016-0323) and Universidad Nacional de La Plata (UNLP) (PPID A-006, 11/X-756). The authors thank Eduardo Denisienia and Jorge

Wagner for their technical support. Author L. M. Julio has received a fellowship from the Consejo Nacional de Investigaciones Científicas y Técnicas (CONICET), Argentina.

This article is protected by copyright. All rights reserved. 


\section{REFERENCES}

1. Rodea-González DA, Cruz-Olivares J, Román-Guerrero A, Rodríguez-Huezo ME, Vernon-Carter EJ and Pérez-Alonso C, Spray-dried encapsulation of chia essential oil (Salvia hispanica L.) in whey protein concentrate-polysaccharide matrices. Journal of Food Engineering 111:102-109 (2012).

2. Ixtaina VY, Julio LM, Wagner JR, Nolasco SM and Tomás MC, Physicochemical characterization and stability of chia oil microencapsulated with sodium caseinate and lactose by spray-drying. Powder Technology 271:26-34 (2015).

3. Escalona-García LA, Pedroza-Islas R, Natividad R, Rodríguez-Huezo ME, CarrilloNavas $\mathrm{H}$ and Pérez-Alonso $\mathrm{C}$, Oxidation kinetics and thermodynamic analysis of chia oil microencapsulated in a whey protein concentrate-polysaccharide matrix. Journal of Food Engineering 175:93-103 (2016).

4. Timilsena YP, Adhikari R, Barrow CJ and Adhikari B, Microencapsulation of chia seed oil using chia seed protein isolate-chia seed gum complex coacervates. International Journal of Biological Macromolecules 91:347-357 (2016).

5. Noello C, Carvalho AGS, Silva VM and Hubinger MD, Spray dried microparticles of chia oil using emulsion stabilized by whey protein concentrate and pectin by electrostatic deposition. Food Research International 89, Part 1:549-557 (2016).

6. González A, Martínez ML, Paredes AJ, León AE and Ribotta PD, Study of the preparation process and variation of wall components in chia (Salvia hispanica L.) oil microencapsulation. Powder Technology 301:868-875 (2016).

7. Chen Q, Zhong F, Wen J, McGillivray D and Quek SY, Properties and stability of spray-dried and freeze-dried microcapsules co-encapsulated with fish oil, phytosterol esters, and limonene. Drying Technology 31:707-716 (2013).

This article is protected by copyright. All rights reserved. 
8. Young S, Sarda X and Rosenberg M, Microencapsulating properties of whey proteins. 2. Combination of whey proteins with carbohydrates. Journal of Dairy Science 76:2878-2885 (1993).

9. Sheu TY and Rosenberg M, Microencapsulation by spray drying ethyl caprylate in whey protein and carbohydrate wall systems. Journal of food science 60:98-103 (1995). 10. Copado CN, Diehl BWK, Ixtaina VY and Tomás MC, Application of Maillard reaction products on chia seed oil microcapsules with different core/wall ratios. LWT Food Science and Technology (2017).

11. Us-Medina U, Julio LM, Segura-Campos MR, Ixtaina VY and Tomás MC, Development and characterization of spray-dried chia oil microcapsules using by-products from chia as wall material. Powder Technology 334:1-8 (2018).

12. Ixtaina VY, Nolasco SM and Tomás MC, Oxidative stability of chia (Salvia hispanica L.) seed oil: effect of antioxidants and storage conditions. Journal of the American Oil Chemists' Society 89:1077-1090 (2012).

13. Frankel EN, Lipid Oxidation: Second Edition. (2005).

14. Aruoma OI, Spencer JPE, Warren D, Jenner P, Butler J and Halliwell B, Characterization of food antioxidants, illustrated using commercial garlic and ginger preparations. Food Chemistry 60:149-156 (1997).

15. Bozin B, Mimica-Dukic N, Simin N and Anackov G, Characterization of the Volatile Composition of Essential Oils of Some Lamiaceae Spices and the Antimicrobial and Antioxidant Activities of the Entire Oils. Journal of Agricultural and Food Chemistry $54: 1822-1828$ (2006).

16. Kulisic $\mathrm{T}$, Radonic $\mathrm{A}$, Katalinic $\mathrm{V}$ and Milos $\mathrm{M}$, Use of different methods for testing antioxidative activity of oregano essential oil. Food Chemistry 85:633-640 (2004).

This article is protected by copyright. All rights reserved. 
17. Viuda-Martos M, Ruiz Navajas Y, Sánchez Zapata E, Fernández-López J and Pérez-Álvarez JA, Antioxidant activity of essential oils of five spice plants widely used in a Mediterranean diet. Flavour and Fragrance Journal 25:13-19 (2010).

18. Zheng W and Wang SY, Antioxidant activity and phenolic compounds in selected herbs. Journal of Agricultural and Food Chemistry 49:5165-5170 (2001).

19. Thorsen MA and Hildebrandt KS, Quantitative determination of phenolic diterpenes in rosemary extracts: aspects of accurate quantification. Journal of Chromatography $A$ 995:119-125 (2003).

20. Mimica-Dukić N, Božin B, Soković M, Mihajlović B and Matavulj M, Antimicrobial and antioxidant activities of three Mentha species essential oils. Planta Medica 69:413-419 (2003).

21. Mimica-Dukic N and Bozin B, Mentha L. Species (Lamiaceae) as Promising Sources of Bioactive Secondary Metabolites. Current Pharmaceutical Design 14:31413150 (2008).

22. Roby $\mathrm{MHH}$, Sarhan MA, Selim KA-H and Khalel KI, Antioxidant and antimicrobial activities of essential oil and extracts of fennel (Foeniculum vulgare L.) and chamomile (Matricaria chamomilla L.). Industrial Crops and Products 44:437-445 (2013).

23. Srivastava JK, Pandey M and Gupta S, Chamomile, a novel and selective COX-2 inhibitor with anti-inflammatory activity. Life Sciences 85:663-669 (2009).

24. Martínez ML, Curti MI, Roccia P, Llabot JM, Penci MC, Bodoira RM and Ribotta PD, Oxidative stability of walnut (Juglans regia L.) and chia (Salvia hispanica L.) oils microencapsulated by spray drying. Powder Technology:271-277 (2015).

25. IUPAC CP, Standard methods for the analysis of oils, fats and derivatives, Ed. Oxford Pergamon Press (1979).

This article is protected by copyright. All rights reserved. 
26. AOCS, Official Methods and Recommended Practices of the AOCS. Champaign (1998).

27. Pharmacopoeia E. Maisonneuve SA,, Sainte-Ruffine, pp 68-71 (1975).

28. Adams R, Identification of essential oil components by gas chromatography/mass spectroscopy. Journal of the American Society for Mass Spectrometry 6:671-672 (1997). 29. Baik MY, Suhendro EL, Nawar WW, McClements DJ, Decker EA and Chinachoti P, Effects of antioxidants and humidity on the oxidative stability of microencapsulated fish oil. Journal of the American Oil Chemists' Society 81:355-360 (2004).

30. Sankarikutty B, Sreekumar M, Narayanan C and Mathew A, Studies on microencapsulation of cardamom oil by spray drying technique. Journal of Food Science and Technology 25 (1988).

31. Quispe-Condori S, Saldaña MD and Temelli F, Microencapsulation of flax oil with zein using spray and freeze drying. LWT-Food Science and Technology 44:1880-1887 (2011).

32. Sousdaleff M, Baesso ML, Neto AM, Nogueira AC, Marcolino VA and Matioli G, Microencapsulation by Freeze-Drying of Potassium Norbixinate and Curcumin with Maltodextrin: Stability, Solubility, and Food Application. Journal of Agricultural and Food Chemistry 61:955-965 (2013).

33. Marcone $\mathrm{M}$ and Kakuda $\mathrm{Y}, \mathrm{A}$ comparative study of the functional properties of amaranth and soybean globulin isolates. Molecular Nutrition \& Food Research 43:368-373 (1999).

34. Rhim J, Wu Y, Weller C and Schnepf M, Physical characteristics of a composite film of soy protein isolate and propyleneglycol alginate. Journal of Food Science 64:149152 (1999).

This article is protected by copyright. All rights reserved. 
35. Comunian TA, Chaves IE, Thomazini M, Moraes ICF, Ferro-Furtado R, de Castro IA and Favaro-Trindade CS, Development of functional yogurt containing free and encapsulated echium oil, phytosterol and sinapic acid. Food Chemistry 237:948-956 (2017).

36. Mancuso JR, McClements DJ and Decker EA, The Effects of Surfactant Type, pH, and Chelators on the Oxidation of Salmon Oil-in-Water Emulsions. Journal of Agricultural and Food Chemistry 47:4112-4116 (1999).

37. Velasco J, Dobarganes $\mathrm{C}$ and Márquez-Ruiz G, Variables affecting lipid oxidation in dried microencapsulated oils. Grasas y aceites 54:304-314 (2003).

38. Belitz H, Grosch W and Schieberle P, Food chemistry. ed, Ed. Springer-Verlag. Berlin Heidelberg (1999).

39. Ayerza R, Oil content and fatty acid composition of chia (Salvia hispanica L.) from five northwestern locations in Argentina. Journal of the American Oil Chemists' Society 72:1079-1081 (1995).

40. Ixtaina VY, Martínez ML, Spotorno V, Mateo CM, Maestri DM, Diehl BWK, Nolasco SM and Tomás MC, Characterization of chia seed oils obtained by pressing and solvent extraction. Journal of Food Composition and Analysis 24:166-174 (2011).

41. Goyal A, Sharma V, Sihag MK, Tomar S, Arora S, Sabikhi L and Singh A, Development and physico-chemical characterization of microencapsulated flaxseed oil powder: A functional ingredient for omega-3 fortification. Powder Technology 286:527-537 (2015).

42. Onwulata C, Konstance R And Holsinger V, Properties of Single-and DoubleEncapsulated Butteroil Powders. Journal of Food Science 63 (1998).

43. Carr Jr RL, Evaluating flow properties of solids. Chemical Engineering (Jan) 18:163-168 (1965).

This article is protected by copyright. All rights reserved. 
44. Geldart D, Harnby N and Wong AC, Fluidization of cohesive powders. Powder Technology 37:25-37 (1984).

45. Laine $\mathrm{P}$, Kylli $\mathrm{P}$, Heinonen $\mathrm{M}$ and Jouppila K, Storage stability of microencapsulated cloudberry (Rubus chamaemorus) phenolics. Journal of Agricultural and Food Chemistry 56:11251-11261 (2008).

46. Danisco TM, Introduction to Guardian ${ }^{T M}$ Chelox (EU) http://cdn.danisco.com/fileadmin/user upload/danisco/documents/products/PB30011US GuardianCheloxL Brochure 01.pdf [July 12nd 2018].

47. Shahidi F, Natural Antioxidants: chemistry, health effects, and applications. The American Oil Chemists Society (1997).

48. Commission CA, Programme JFWFS and Organization WH, Codex alimentarius commission: procedural manual. Food \& Agriculture Org. (2007).

49. Binsi PK, Nayak N, Sarkar PC, Jeyakumari A, Muhamed Ashraf P, Ninan G and Ravishankar CN, Structural and oxidative stabilization of spray dried fish oil microencapsulates with gum arabic and sage polyphenols: Characterization and release kinetics. Food Chemistry 219:158-168 (2017).

50. Pathare PB, Opara UL and AI-Said FA-J, Colour measurement and analysis in fresh and processed foods: a review. Food and Bioprocess Technology 6:36-60 (2013). 51. Adekunte AO, Tiwari BK, Cullen PJ, Scannell AGM and O'Donnell CP, Effect of sonication on colour, ascorbic acid and yeast inactivation in tomato juice. Food Chemistry 122:500-507 (2010).

This article is protected by copyright. All rights reserved. 


\section{FIGURE LEGENDS}

Figure 1. Micrographs obtained by Scanning Electronic Microscopy (SEM) of the outer morphology of freeze-dried chia oil microparticles a) 50x; b) 100x; c) 800x; d) 3000x; pores (po) and protrusions (pr) are indicated

Figure 2. Induction times $\left(\mathrm{t}_{\mathrm{i}}\right)$ obtained from the Rancimat method $\left(\mathrm{T}=98^{\circ} \mathrm{C}\right.$, air flow 20 $\mathrm{L} / \mathrm{h}$ ) of freeze-dried microencapsulated chia seed oil (without and with the addition natural of antioxidants) at $\mathrm{t}=0$ (immediately after microparticles production) and at $\mathrm{t}=90 \mathrm{~d}$ of microparticles stored at $25 \pm 2^{\circ} \mathrm{C}$ and $33 \% \mathrm{RH}$. Values are the mean of the two independent batches $(n=2)$ and bars indicate standard deviation

Figure 3. Peroxide value of chia oil and freeze-dried chia oil powders (without and with the addition of natural antioxidants) stored at $25 \pm 2{ }^{\circ} \mathrm{C}$ and $33 \% \mathrm{RH}$ during 90 days. Values are the mean \pm standard deviation of two independent batches $(n=2)$

This article is protected by copyright. All rights reserved. 
Table 1. Composition of the different chia O/W emulsions previous to freeze-drying

\begin{tabular}{|c|c|c|c|c|c|c|c|c|c|}
\hline \multirow{2}{*}{ Composition } & \multicolumn{9}{|c|}{ Emulsion } \\
\hline & 1 & 2 & 3 & 4 & 5 & 6 & 7 & 8 & 9 \\
\hline Chia seed oil ( $\left.\mathrm{g} \mathrm{kg}^{-1} \mathrm{emulsion}\right)$ & 100 & 100 & 100 & 100 & 100 & 100 & 100 & 100 & 100 \\
\hline Water (g kg-1 emulsion) & 700 & 700 & 700 & 700 & 700 & 700 & 700 & 700 & 700 \\
\hline caseinate ( $\mathrm{g} \mathrm{kg}^{-1}$ emulsion) & 100 & 100 & 100 & 100 & 100 & 100 & 100 & 100 & 100 \\
\hline ( $\mathrm{g} \mathrm{kg}^{-1}$ emulsion $)$ & 100 & 100 & 100 & 100 & 100 & 100 & 100 & 100 & 100 \\
\hline ian Chelox ( $\mathrm{mg} \mathrm{kg}^{-1}$ emulsion) & - & 500 & 1000 & - & - & - & - & - & - \\
\hline are essential oil ( $\mathrm{mg} \mathrm{kg}^{-1}$ emulsion) & - & - & - & 500 & 1000 & - & - & - & - \\
\hline O. $x$ majoricum essential oil (mg kg ${ }^{-1}$ emulsion) & - & - & - & - & - & 500 & 1000 & - & - \\
\hline itha spicata essential oil ( $\mathrm{mg} \mathrm{kg}^{-1}$ emulsion) & - & - & - & - & - & - & - & 500 & 1000 \\
\hline & C & GCH500 & $\mathrm{GCH} 1000$ & Ov500 & Ov1000 & Om500 & Om1000 & M500 & M1000 \\
\hline
\end{tabular}

This article is protected by copyright. All rights reserved. 
Table 2. Major chemical compounds (> 1\%) in essential oils of $O$. vulgare, $O . x$ majoricum and M.spicata

\begin{tabular}{|c|c|c|c|c|c|}
\hline \multirow[t]{2}{*}{ Peak } & \multirow[t]{2}{*}{ Compound } & \multirow[t]{2}{*}{ RT (min) } & O. vulgare & O. x majoricum & M. spicata \\
\hline & & & \multicolumn{3}{|c|}{$\%$ relative } \\
\hline 1 & $\beta$-phellandrene & 9.18 & ND & 2.49 & ND \\
\hline 2 & $\beta$-myrcene & 9.57 & 1.30 & 1.00 & 2.15 \\
\hline 3 & $\alpha$ - terpinene & 10.08 & 1.40 & 3.66 & ND \\
\hline 4 & cymol & 10.23 & 13.42 & 7.00 & ND \\
\hline 5 & d-limonene & 10.32 & ND & 1.55 & 36.37 \\
\hline 6 & V- terpinene & 10.91 & 6.96 & 5.79 & ND \\
\hline 7 & terpineol & 11.63 & TR & 23.10 & ND \\
\hline 8 & menthone & 12.60 & ND & ND & 5.05 \\
\hline 9 & menthol & 12.92 & ND & ND & 1.90 \\
\hline 10 & terpinen-4-ol & 12.99 & TR & 11.94 & ND \\
\hline 11 & dihydrocarveol & 13.28 & ND & ND & 3.08 \\
\hline 12 & carvone & 14.01 & ND & 1.52 & 45.36 \\
\hline 13 & thymol & 14.69 & TR & 26.20 & ND \\
\hline 14 & carvacrol & 14.81 & 72.00 & 9.08 & ND \\
\hline \multirow[t]{2}{*}{15} & caryopyllene & 16.56 & 1.00 & 1.89 & 1.20 \\
\hline & others* & & 3.92 & 4.78 & 4.89 \\
\hline
\end{tabular}

RT: retention time; ND: no detected; TR: traces ( $<1 \%)$

* Sum of different compounds $<1 \%$

This article is protected by copyright. All rights reserved. 
Tabla 3. Physicochemical properties of control microparticles containing chia seed oil obtained by freeze-drying.

\begin{tabular}{lc}
\hline Property & Value \\
\hline Total oil $\left(\mathrm{g} \mathrm{kg}^{-1}\right)$ & $325 \pm 2.0$ \\
Surface oil $\left(\mathrm{g} \mathrm{kg}^{-1}\right)$ & $44.5 \pm 2.0$ \\
Microencapsulation efficiency (ME) (\%) & $86.3 \pm 3.2$ \\
Moisture content $\left(\mathrm{g} \mathrm{kg}^{-1}\right)$ & $38.1 \pm 4.0$ \\
Bulk Density $\left(\mathrm{kg} \mathrm{m}^{-3}\right)$ & $310 \pm 10$ \\
$\quad$ Aerated & $410 \pm 20$ \\
$\quad$ Tapped & $24.39 \pm 0.84$ \\
Compressibility Index (\%) & $1.32 \pm 0.01$ \\
Hausner ratio $(\mathrm{H})$ & $13.5 \pm 1.6$ \\
Oxidative stability ( $\mathrm{t}_{\mathrm{i}}$ in $\left.\mathrm{h}\right)$ & $0.8 \pm 0.05$ \\
Peroxide value (meq kg & \\
\hline Mean values \pm standard deviation $(\mathrm{n}=2)$. &
\end{tabular}

This article is protected by copyright. All rights reserved. 
Tabla 4. Color parameters of the powders containing chia seed oil without and with natural antioxidants during the storage at $25 \pm 2{ }^{\circ} \mathrm{C}$ and $33 \% \mathrm{RH}$

\begin{tabular}{|c|c|c|c|c|c|c|c|c|c|c|c|}
\hline \multirow{2}{*}{$\begin{array}{c}\text { Microencapsulated } \\
\text { chia oil }\end{array}$} & \multicolumn{4}{|c|}{$t=0 d$} & \multicolumn{6}{|c|}{$t=90 d$} & \multirow{2}{*}{$\Delta \mathrm{E}$} \\
\hline & $\mathrm{L}^{*}$ & $a^{*}$ & $b^{*}$ & W & $\mathrm{Y}$ & $L^{*}$ & $a^{*}$ & $b^{*}$ & W & $\bar{Y}$ & \\
\hline C & $90.72^{\mathrm{ab} \mathrm{B}}$ & $-2.63^{\mathrm{a} A}$ & $16.29^{\mathrm{b} A}$ & $41.85^{\mathrm{a} B}$ & $25.65^{\mathrm{DA}}$ & $84.50^{\mathrm{a} A}$ & $1.095^{\mathrm{e} B}$ & $31.99^{\mathrm{CB}}$ & $-11.47^{a A}$ & $54.13^{\mathrm{CB}}$ & $17.41^{\mathrm{c}}$ \\
\hline GCH500 & $91.33^{\mathrm{ab} A}$ & $-1.77^{\mathrm{b} A}$ & $14.64^{\mathrm{a} \mathrm{A}}$ & $47.41^{\mathrm{b} \mathrm{B}}$ & $22.91^{\mathrm{aA}}$ & $90.45^{\mathrm{bc} \mathrm{A}}$ & $-1.78^{\mathrm{cA}}$ & $16.40^{\mathrm{a} B}$ & $41.25^{\mathrm{cA}}$ & $25.90^{\mathrm{a} B}$ & $2.24^{a}$ \\
\hline $\mathrm{GCH} 1000$ & $89.72^{\mathrm{a} A}$ & $-1.29^{\mathrm{CA}}$ & $14.87^{\mathrm{ab} \mathrm{A}}$ & $45.11^{\mathrm{ab} \mathrm{B}}$ & $23.67^{\mathrm{ab} \mathrm{A}}$ & $88.23^{\mathrm{b} A}$ & $-1.26^{\mathrm{d} A}$ & $15.85^{\mathrm{a} B}$ & $40.67^{\mathrm{CA}}$ & $25.67^{\mathrm{a} B}$ & $1.84^{\mathrm{a}}$ \\
\hline Ov500 & $92.25^{\mathrm{bA}}$ & $-2.11^{\mathrm{bB}}$ & $14.91^{\mathrm{ab} \mathrm{A}}$ & $47.51^{\mathrm{b} B}$ & $23.10^{\mathrm{a} A}$ & $91.04^{\mathrm{cA}}$ & $-2.52^{\mathrm{aA}}$ & $17.54^{\mathrm{a} B}$ & $38.41^{\mathrm{cA}}$ & $27.54^{\mathrm{a} B}$ & $2.98^{a}$ \\
\hline Ov1000 & $92.02^{\mathrm{bA}}$ & $-2.05^{\mathrm{b} B}$ & $14.62^{\mathrm{a} A}$ & $48.17^{\mathrm{b} B}$ & $22.72^{\mathrm{aA}}$ & $91.63^{\mathrm{CA}}$ & $-2.23^{\mathrm{b} \mathrm{A}}$ & $16.14^{\mathrm{a} B}$ & $43.21^{\mathrm{cA}}$ & $25.18^{a \mathrm{~B}}$ & $1.97^{\mathrm{a}}$ \\
\hline Om500 & $92.43^{\mathrm{b} \mathrm{A}}$ & $-1.98^{\mathrm{b} B}$ & $14.45^{\mathrm{a} A}$ & $49.09^{b B}$ & $22.33^{\mathrm{aA}}$ & $92.27^{\mathrm{CA}}$ & $-2.32^{\mathrm{ab} \mathrm{A}}$ & $16.58^{\mathrm{a} B}$ & $42.53^{\mathrm{CA}}$ & $25.67^{\mathrm{a} B}$ & $2.23^{a}$ \\
\hline Om1000 & $92.02^{\mathrm{bA}}$ & $-2.05^{\mathrm{b} B}$ & $14.31^{\mathrm{aA}}$ & $49.08^{b B}$ & $22.22^{\mathrm{aA}}$ & $91.27^{\mathrm{CA}}$ & $-2.35^{\mathrm{ab} \mathrm{A}}$ & $15.85^{\mathrm{a} B}$ & $43.72^{\mathrm{CA}}$ & $24.81^{a B}$ & $1.79^{a}$ \\
\hline M500 & $91.83^{\mathrm{bB}}$ & $-1.99^{\mathrm{b} B}$ & $15.10^{\mathrm{ab} \mathrm{A}}$ & $46.51^{\mathrm{ab} B}$ & $23.50^{\mathrm{ab} \mathrm{A}}$ & $90.07^{\mathrm{bc} A}$ & $-2.17^{\mathrm{b} A}$ & $22.74^{\mathrm{bB}}$ & $21.83^{\mathrm{b} A}$ & $36.09^{b B}$ & $7.89^{b}$ \\
\hline M1000 & $91.32^{\mathrm{ab} \mathrm{A}}$ & $-1.95^{\mathrm{b} B}$ & $14.80^{\mathrm{a} A}$ & $46.91^{\mathrm{ab} \mathrm{B}}$ & $23.16^{\mathrm{ab} \mathrm{A}}$ & $90.74^{\mathrm{cA}}$ & $-2.43^{\mathrm{ab} \mathrm{A}}$ & $17.66^{a B}$ & $37.75^{\mathrm{cA}}$ & $27.81^{a \mathrm{~B}}$ & $3.04^{a}$ \\
\hline
\end{tabular}

Mean values $(n=3)$. Different lowercase letters in each column indicate differences in each color parameter between systems with different antioxidants (Tukey test, $p \leq 0.05$ ). Different uppercase letters in each row indicate, for each system, differences in the color parameter between the initial $(t=0)$ and final $(t=90 \mathrm{~d})$ storage time (Tukey test, $p \leq 0.05)$.

This article is protected by copyright. All rights reserved. 
Figure 2
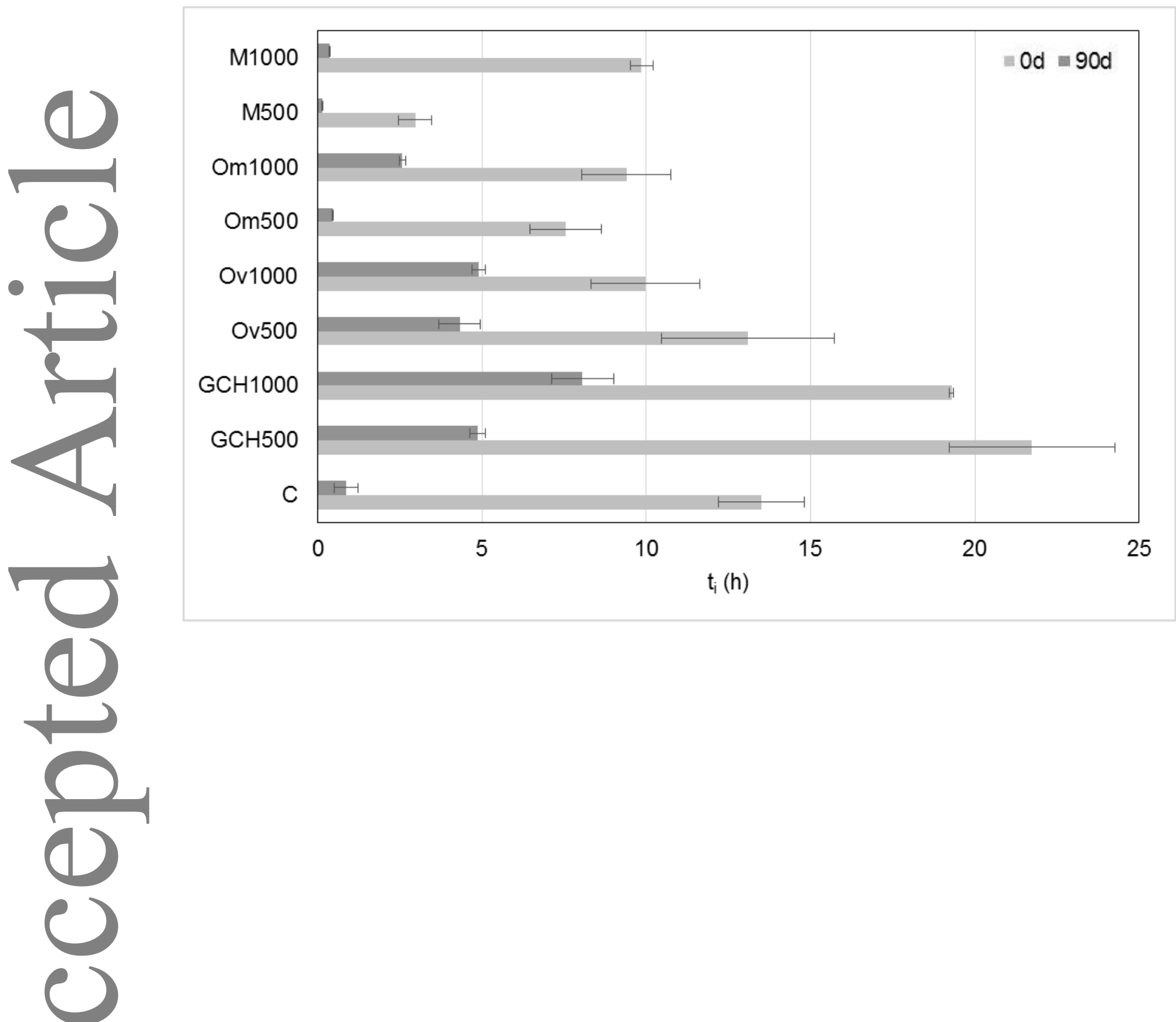

This article is protected by copyright. All rights reserved. 
Figure 3
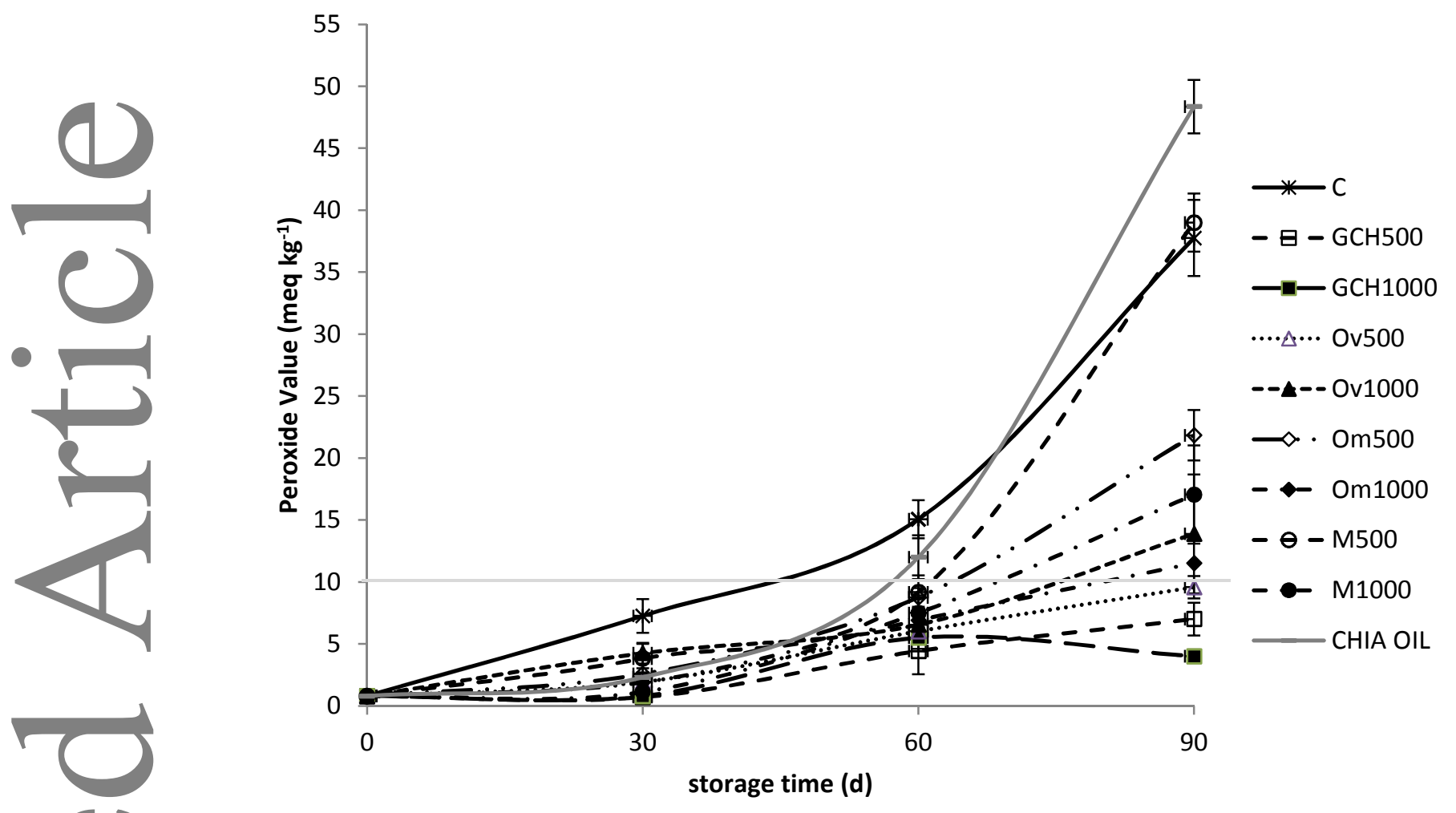

This article is protected by copyright. All rights reserved. 